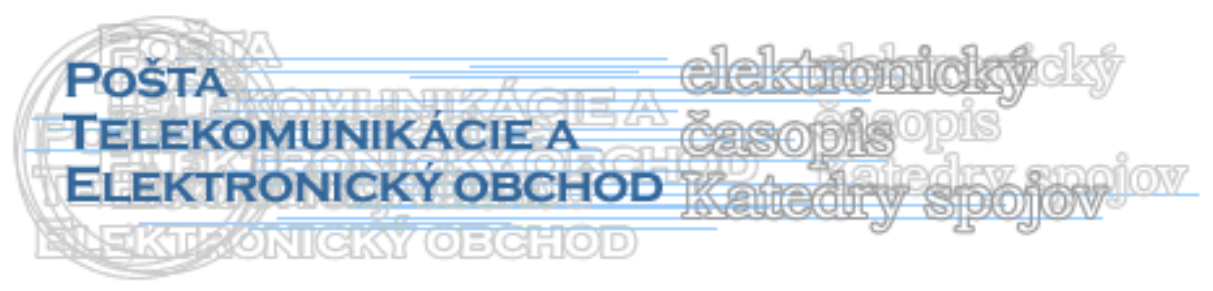

\title{
POROVNANIE PLATOBNÝCH BRÁN
}

\author{
Peter Jucha ${ }^{1}$, Tatiana Čorejová ${ }^{2}$
}

\begin{abstract}
There are various risks associated with online payment, such as theft of funds or misuse of personal data. For this reason, there are payment gateways that allow you to make secure payments for products purchased online. But there are already many of them today. The aim of the paper is to find out, based on the analysis and comparison of secondary sources, which payment gateways are currently considered the most used according to these sources and to compare them with each other.
\end{abstract}

Keywords: e-commerce, e-payment, payment gateway.

\section{Úvod}

Elektronický obchod je pojem, ktorý úzko súvisí s digitálnym trhom. Rozumieme pod ním systém, ktorého súčast'ou sú rôzne druhy transakcií. Ide o obchod, ktorý je realizovaný s využitím elektronických komunikačných sietí. Zo strany spotrebitel'ov predstavuje pohodlný spôsob ako sa dostat' k rôznym produktom, prípadne si objednat' rôzne služby z pohodlia domova či určitého miesta. Prostredníctvom osobných počítačov, mobilov, tabletov alebo aj iných technologických prostriedkov, na ktorých l'udia i firmy využívajú pripojenie k sieti, si môžu prezriet' ponuku produktov jednotlivých obchodov a podnikov $[1,2]$.

$Z$ dôvodu skutočnosti, že nedochádza k priamemu kontaktu medzi predajcom a spotrebitel'om, je nutné presne vymedzit' obchodné vzt'ahy medzi subjektami, ktoré musia rešpektovat' platné legislatívne predpisy. Podstatou obchodu, ktorý je realizovaný prostredníctvom elektronických komunikačných sietí či prostredníctvom rôznych platforiem, je dôvera, ktorá sa stala kl’účovým determinantom nákupného zámeru spotrebitel’a či zákazníka. Znamená to, že produkt, ktorý si zákazník objednal, bude doručený v požadovanej kvalite, množstve, na čas a bez vopred neuvedených poplatkov. Významným aspektom sa tak stáva otázka ochrany spotrebitel'a a zákazníka, ako aj bezpečnost'. Z toho dôvodu sú platobné systémy a elektronické platby rozhodujúcim a podstatným faktorom elektronického obchodu. $[3,4]$

\section{Teoretický rámec}

\section{Elektronický platobný systém}

Elektronický platobný systém (EPS) je systém organizovaný tak, aby bolo možné platit' za služby prostredníctvom rôznych on-line služieb, programov alebo kariet, ktoré umožňujú previest' peniaze na účet bez akýchkol'vek d'alších akcií s bankovkami. Predstavuje

\footnotetext{
${ }^{1}$ Ing. Peter Jucha, Katedra spojov, FPEDAS, Žilinská univerzita v Žiline, e-mail: peter.jucha@fpedas.uniza.sk

${ }^{2}$ Dr.h.c. prof. Ing. Tatiana Čorejová, PhD., Katedra spojov, FPEDAS, Žilinská univerzita v Žiline, e-mail: tatiana.corejova@fpedas.uniza.sk
} 
kolekciu hardvérových zariadení, informačných sietí a organizačných štruktúr, ktoré užívatel'om poskytujú jednu alebo aj viac druhov platieb, medzi ktoré patria napríklad $[5,6]$ :

- dial'kový prevod elektronických peňazí,

- platby pomocou plastových kariet s magnetickými prúžkami alebo čipových kariet,

- prijímanie alebo platby v hotovosti od fyzických osôb.

Elektronické platobné systémy sú schopné implementovat' štátne ale aj komerčné organizácie. Prostredníctvom týchto systémov sú potom uskutočnené platby za tovary, služby a prácu. Hotovost' je prijímaná v úverových inštitúciách. Medzi elektronické platobné systémy sa zarad'ujú aj bankové a nebankové platobné terminály, finančné služby na dial'ku a aj služby vzdialeného bankovníctva (RBS) zahíňajúce internetové bankovníctvo, SMS bankovníctvo, mobilné bankovníctvo, mobilné finančné služby mobilných operátorov a aj elektronické peniaze. [6]

\section{Elektronické platby (e-platby)}

Elektronickú platbu (e-platbu) možno definovat' ako platbu za tovar alebo služby, uskutočnenú prostredníctvom elektronických komunikačných sietí a služieb. Zahŕňa všetky finančné operácie využívajúce elektronické zariadenia akými sú počítače, smartfóny alebo tablety. Rozmach elektronického obchodu spolu s rozvojom a rozmachom internetu podporil aj digitalizáciu platobného procesu poskytovaním rôznych online platobných metód, medzi ktoré v súčasnosti patria: elektronická hotovost', debetné karty, kreditné karty, bezkontaktné platby, mobilné peňaženky a d'alšie metódy. Elektronické platby sa vo všeobecnosti považujú za rýchlu a bezpečnú alternatívu k tradičným platobným metódam, ako sú bankové prevody, šeky atd'. Svojou jednoduchost'ou a rýchlost'ou výrazne pomáhajú rozvoju elektronického obchodu a elektronického podnikania. [7, 8, 9]

Online platby sa uskutočňujú okamžite, čo znamená, že je to pohodlný spôsob platenia a šetrí vel'a času. Dôležitou súčast'ou procesu sú pri tom aj platobné brány, ktorá kontrolujú či sú všetky uvedené informácie, týkajúce sa platby, v poriadku. [8]

\section{Elektronická platobná brána}

Elektronická platobná brána je technológia, alebo inak platforma, ktorá umožňuje realizovat' bezpečné platby za produkty kúpené v online priestore a ktorú tak obchodníci používajú na prijímane nákupov uskutočnených debetnými alebo kreditnými kartami od zákazníkov. Reálne je v nej združených viacero platobných metód, akými sú aj platba online bankovým tlačidlom, prevod na bankový účet, mobilné platby, elektronické peňaženky, platby kupónmi, platby bitcoinami a pod. Výraz „platobná brána“ nezahŕňa iba fyzické zariadenia, určené na čítanie kariet a nachádzajúce sa v kamenných maloobchodných predajniach, ale aj portály určené na spracovanie platieb. Dôležitými vlastnost'ami platobných brán sú predovšetkým bezpečnost', spol'ahlivost', jednoduchost' používania, ako aj možnost' výberu dostatku platobných metód. [10,11, 12]

Platobná brána predstavuje kl'účovú súčast' elektronického spracovania platieb. Je to technológia zodpovedná za zasielanie informácií o zákazníkovi do banky obchodníka, kde je transakcia následne spracovaná. Technológie platobných brán sa neustále vyvíjajú a dnes majú zákazníci k dispozícii napríklad bezkontaktné nákupy, pri ktorých vel’a zákazníkov využíva svoje smartfóny ako platobné zariadenie, oproti minulosti, kedy terminály prijímali kreditné karty pomocou magnetických prúžkov, čo ešte vyžadovalo od zákazníka podpis. [10]

Aj ked' samotná platba kartou prebehne prostredníctvom platobnej brány za pár sekúnd, na pozadí prebieha intenzívna spolupráca viacerých systémov:

1. Zákazník vyplní údaje potrebné k uskutočneniu platby v rozhraní platobnej brány a tieto informácie sú následne zašifrované a odoslané k spracovatel'ovi transakcie, ktorý používa banka obchodníka. 
2. Spracovatel' transakcie odosiela transakčné informácie do systémov kartových asociácií.

3. Kartová asociácia príjme žiadost' o autorizáciu a zabezpečí napojenie transakcie na systém vydavatel'a platobnej karty. Následne u vydavatel’a overí, či sú údaje správne vyplnené a či je dostatok prostriedkov na účte majitel'a karty, a potom odošle odpoved', o tom či je platba prijatá alebo zamietnutá, spät' spracovatel'ovi transakcie.

4. Spracovatel' transakcie prepošle informácie platobnej bráne a tá ju odošle na webovú stránku obchodníka. Tento proces sa nazýva „Autorizácia“ a trvá približne 2 až 3 sekundy. Ak je platba schválená, suma na obchodnom účte e-shopu je platobnou bránou navýšená.

5. Informácia o tom, či bola platba prijatá alebo zamietnutá, je vrátená e-shopu a na základe toho obchodník splní objednávku.

6. Na konci dňa je platobnou bránou vykonaný proces, ktorý sa nazýva „Vyrovnanie“. Ide o proces. kedy sú zoskupené všetky transakcie a prostredníctvom procesora na vyrovnanie sú peniaze odoslané na bankový účet e-shopu na základe dohodnutej frekvencie zúčtovania. $[12,13]$

\section{Ciel' a metodológia}

Hlavným ciel'om príspevku bolo určit' a analyzovat', ktoré z platobných brán, ktoré sa používajú pri nákupe či objednaní tovaru prostredníctvom elektronického obchodu či e-shopu, patria v súčasnosti medzi najznámejšie a často používané. Na dosiahnutie tohto ciel'a sme vychádzali z analýzy sekundárnych zdrojov, ktoré sa touto témou zaoberajú, a následnej komparácie.

Východiskovými sekundárnymi zdrojmi boli články z renomovaných databáz (web of science, Scopus, EconLit) a internetové zdroje odkazujúce na tému elektronického obchodovania, elektronických platieb a platobných brán, či už na Slovensku alebo v zahraničí.

$\mathrm{V}$ rámci analýzy boli charakterizované vybrané platobné brány a následná komparácia mala za ciel' porovnat' početnosti výskytu jednotlivých platobných brán v sekundárnych informačných zdrojoch. Následne bol vytvorený zoznam platobných brán podl'a početností, t.j. kol'kokrát bola konkrétna platobná brána spomenutá $v$ jednotlivých informačných zdrojoch.

\section{Výsledky}

Integrovaná online platobná brána je jednou z najdôležitejších funkcií každej webovej stránky elektronického obchodu, nakol'ko zabezpečenie bezpečného procesu platby je absolútne nevyhnutné. Jednotlivé platobné brány ale vykazujú medzi sebou rozdiely. [14]

Nasledujúci zoznam tak uvádza platobné brány, ktoré podl'a určitých zdrojov patria do roku 2020 z globálneho hl'adiska medzi tie najpoužívanejšie.

\section{PayPal}

Spoločnost' bola založená v roku 1998 ako Cofinity. Je pravdepodobne najbežnejšou používanou platobnou bránou, ktorá už v čase jej vzniku umožňovala odosielat' a prijímat' platby po celom svete, pričom všade je akceptovaná dodnes, a patrí medzi lídra v oblasti spracovania platieb. Služba PayPal umožňuje prijímat' a odosielat' online platby jednotlivcom aj firmám, poskytuje aukčné stránky a umožňuje prijímat' kreditné karty. Takisto ponúka aj l’ahkú integráciu nákupného online košíka, množstvo možností prispôsobenia, online fakturáciu a ul'ahčuje napríklad aj platby kreditnou kartou po telefóne. Reputáciu si drží aj vd'aka jednoduchému použitiu, spol'ahlivosti a bezpečnosti. Služba spĺn̆a bezpečnostné štandardy PCI DS. Zákazníkom ponúka napríklad ochranu v prípade, že im zakúpený tovar nedorazí, alebo pokial' nezodpovedá popisu. Je tak možné získat' naspät' plnú, alebo aspoň 
čiastočnú, platbu za tovar vrátane poštovného. Taktiež chráni aj predajcov voči neautorizovaným platbám. Je k dispozícii v 203 krajinách sveta, peňažné prostriedky je možné vyberat' až v 56 rôznych menách a má viac ako 200 miliónov aktívnych používatel'ov. Niektoré zdroje uvádzajú, že ich je až okolo 300 miliónov. [11, 12, 14, 15, 16, 17]

\title{
Stripe
}

Ide o medzinárodnú platformu vyvinutú americkou firmou, ktorá bola spustená v roku 2011. Stripe je podobný PayPalu z toho hl'adiska, že uživatel'ské rozhranie je jednoduché na používanie, nevyžaduje žiadny mesačný ani členský poplatok a ponúka bezpečné nakupovanie v sieti internetu. Hlavným rozdielom, medzi touto službou a mnohými inými je ten, že nejde o hotové riešenie ako napríklad v prípade PayPalu. Platforma má k dispozícii rad flexibilných nástrojov určených na prispôsobenie platobných procesov konkrétnych používatel'ov. Stripe je navrhnutý predovšetkým pre väčšie firmy a ponúka im množstvo rozmanitých rozhraní API, ktoré týmto firmám umožňujú vytvárat' prispôsobené platobné služby od vlastných predplatných služieb cez trhoviská na požiadanie, alebo platformy kolektívneho financovania až po platby $\mathrm{v}$ aplikácii. Je $\mathrm{v}$ ňom podporovaná celá rada vývojových jazykov, akými sú napríklad Ruby, Python, PHP a Java. Okrem toho Stripe ponúka prispôsobené možnosti určovania cien pre tých obchodníkov, ktorí majú jedinečný obchodný model, alebo majú vel'ké objemové platby. Stripe splńa najvyššie bezpečnostné štandardy kartových asociácií PCI DSS a má aj výnimočnú technickú podporu a zákaznícke služby, v rámci ktorých je možné jeho zástupcov kontaktovat' nepretržite prostredníctvom telefónu, chatu alebo e-mailu. Stripe akceptuje možnost' platby vo viac ako 100 menách a podporuje viac ako 300 integrácií, akou je napríklad platba jedným kliknutím. [12, 14, 15, $16,17]$

\begin{abstract}
Adyen
Predstavuje špičkovú holandskú platformu na spracovanie platieb, ktorá je technologicky vel'mi zdatná. Používatel'om umožňuje prijímat' všetky platby uskutočnené v rámci ich spoločnosti z jednej platformy a poskytuje im nástroje na riadenie rizík, ktoré kontrolujú údaje za účelom identifikácie, boja proti prípadom podvodu a sledovanie výsledkov hospodárenia. Platforma spracovala v roku 2019 platobné transakcie v hodnote viac ako 130 miliárd EUR a rovnako vyhrala $v$ tomto roku aj ocenenie Nora Solution Partner Excellence Awards za najlepšie riešenie zabezpečenia a boja proti podvodom. Adyen využívajú spoločnosti, akými sú Uber, Spotify, Microsoft a eBay na vybavovanie obchodných a zákazníckych transakcií. Platforma je k dispozícii v 200 krajinách sveta a okrem toho, že podporuje 250 platobných metód a 150 globálnych mien, umožňuje taktiež analyzovat' údaje o vykonaných transakciách. $[14,15,17]$
\end{abstract}

\section{Braintree}

Firma Braintree bola založená v roku 2007 v USA a v roku 2013 ju získala firma PayPal. V súčasnosti má 7 globálnych pobočiek a to v New Yorku, Chicagu, San Franciscu, Austine, Londýne, Sydney a v Singapure. Strategicky sa zameriava na používatel'ov mobilných telefónov. Spĺn̆a bezpečnostné kritéria PCI DSS Level 1 kartových spoločností a dôverujú jej vel'ké digitálne spoločnosti, akými sú Airbnb a Uber. Ročne spracováva viac ako 4 miliardy transakcií a je rozšírená do 45 krajín sveta. Obsahuje aj špeciálne nástroje na detekciu podvodov. [12, 17] 


\section{Výhody a nevýhody platobných brán}

Vyššie spomenuté platobné brány patria medzi tie, ktoré sú na základe viacerých internetových zdrojov považované v rámci sveta za najlepšie a najpoužívanejšie. Každá z nich má určité výhody a nevýhody, ktoré sú uvedené v Tabul'ke 1.

Tabul'ka 1: Porovnanie výhod a nevýhod najlepších a najpoužívanejších platobných brán na svete

\begin{tabular}{|c|c|c|}
\hline $\begin{array}{c}\text { Platobná } \\
\text { brána }\end{array}$ & Výhody & Nevýhody \\
\hline PayPal & $\begin{array}{ll}\text { - } & \text { vel'a používatel'ských účtov; } \\
\text { - } & \text { dôveryhodnost' služby; } \\
\text { - } & \text { možnosti prispôsobenia; } \\
\text { - } & \text { bez poplatkov za zavedenie } \\
& \text { a správu }\end{array}$ & $\begin{array}{l}\text { - absencia kvalitného } \\
\text { zákazníckeho servisu, pomoc } \\
\text { formou automatických mailov }\end{array}$ \\
\hline Stripe & $\begin{array}{ll}\text { - } & \text { vstavané API a vývojárske } \\
\text { nástroje; } \\
\text { - } & \text { mobilné platby; } \\
\text { - } & \text { rýchle a jednoduché riešenie } \\
& \text { pre platby kartou; } \\
\text { - } & \text { umožňuje bankové prevody; } \\
\text { - } & \text { elektronické peňaženky AliPay, } \\
& \text { Google Pay, Apple Pay, } \\
\text { Microsoft Pay, Masterpass } \\
\text { a d'alšie }\end{array}$ & $\begin{array}{ll}\text { - } & \text { nie je možnost' mobilnej brány; } \\
\text { - } & \text { pri platbe v inej mene, ako je } \\
\text { priradená ku Stripe kontu, je } \\
\text { účtovaný poplatok za prevod } \\
\text { medzi menami; } \\
\text { - } \quad \text { nie je predautorizovaná platba; } \\
\text { - } \quad \text { platobný link nie je možné } \\
\text { poslat' mailom }\end{array}$ \\
\hline Adyen & $\begin{array}{ll}\text { - } & \text { funguje na jednej platforme; } \\
\text { - } & \text { určená pre vel'ké firmy; } \\
\text { - } & \text { integrovaný prehl'ad údajov; } \\
\text { - } & \text { možnost' vrátenia platby } \\
& \text { jedným kliknutím na pôvodný } \\
\text { zdroj }\end{array}$ & $\begin{array}{ll}\text { - } & \text { komplexná cenová štruktúra; } \\
\text { - } & \text { pri vyhl'adávaní podrobností } \\
& \text { o platbách sa zobrazuje iba } \\
& \text { meno držitel'a karty; } \\
\text { - } & \text { dizajn webových stránok; } \\
\text { - } & \text { obsahuje iba funkciu zakázania } \\
& \text { podrobností o kreditnej karte } \\
& \text { namiesto ich úplného } \\
& \text { odstránenia }\end{array}$ \\
\hline Braintree & $\begin{array}{l}\text { - } \begin{array}{l}\text { možnost' integrácie brány do } \\
\text { mobilnej aplikácie; }\end{array} \\
\text { - } \quad \text { elektronické peňaženky PayPal, } \\
\text { Venmo, Apple Pay, Google } \\
\text { Pay; } \\
\text { - } \\
\text { možnost' dokúpenia služieb pre } \\
\text { zvýšenie bezpečnosti } \\
\text { transakcií; } \\
\text { - } \\
\text { API rozhranie a sandbox } \\
\text { prostredie na testovanie }\end{array}$ & 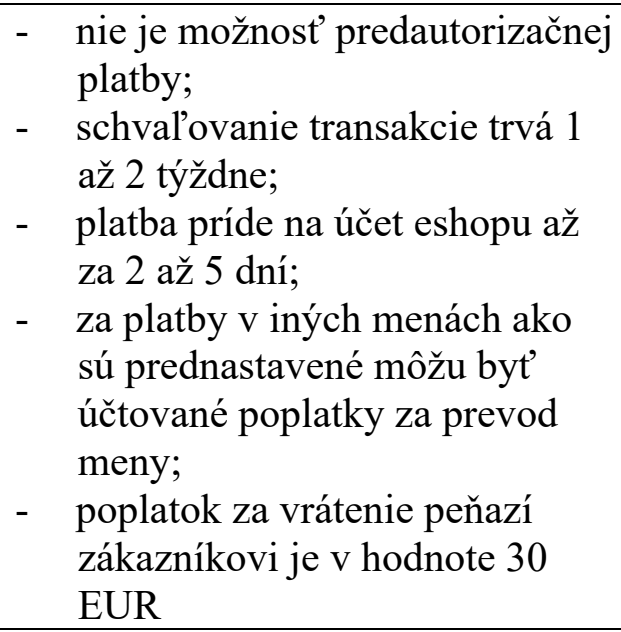 \\
\hline
\end{tabular}

Zdroj: vlastné spracovanie podl'a $[12,15,18,19]$ 


\section{Záver}

$\mathrm{Na}$ základe uskutočnenej analýzy a porovnania rôznych zdrojov je vidiet', že v súčasnosti je pravdepodobne jednou z najpoužívanejších platobných brán na svete PayPal. Analyzovaných a porovnávaných bolo 6 zoznamov, v ktorých boli podl'a ich autorov uvedené najlepšie a najpoužívanejšie platobné brány do roku 2020, pričom PayPal bol spomenutý v každom z nich. Výhodou tejto platformy je, že existuje od roku 1998 a jej dôveryhodnost' a bezpečnost' potvrdzuje v súčasnosti už vel'ká používatel'ská základňa.

Hned' za ním sa nachádza Stripe, ktorý sa spomínal v 5 analyzovaných zdrojoch. Jeho výhodou je, že ide o odlišnejšiu platformu, ako je väčšina ostatných, a to najmä v tom, že je určený predovšetkým pre vel'ké firmy, ktoré si prostredníctvom tejto platformy môžu upravovat' a prispôsobovat' svoje platobné služby.

Poslednými spomenutými platobnými bránami sú Adyen a Braintree, ktoré sa v analyzovaných zdrojoch vyskytli iba 2 až 3 krát. Napriek tomu boli ale spomenuté častejšie ako mnoho iných d'alších platobných brán. Výhodou Adyen je, že všetky platby sa uskutočňujú v rámci jednej platformy, a platobná brána Braintree sa zase zameriava na používatel'ov mobilných telefónov.

Poslednú skupinu tak tvoria všetky ostatné platobné brány. Celkovo ich dnes už existuje vel'mi vel'a no napriek tomu nie všetky sú pravdepodobne tak rozšírené ako štyri vyššie spomenuté a používatelia ich nevyužívajú tak často a v tak vel'kej miere. Patria sem napríklad nasledovné platobné brány: Twisto, Barion, PayU, Google Pay, Amazon Pay a mnoho d’alších, ale napríklad aj slovenská platobná brána Besteron alebo česká GoPay.

\section{Literatúra}

[1] MADLEŇÁK, R.: Elektronický obchod, Žilina : Žilinská univerzita, 2004.,160 s., ISBN 80-8070-192-X. [cit. 08. 07. 2020].

[2] JUCHA, P. Analýza vplyvov jednotného digitálneho trhu na spotrebitela, Žilina: Žilinská univerzita, 2017, 50 str.

[3] MADLEŇÁKOVÁ, L., MIŠÍKOVÁ, M., MADLEŇÁK, R.: Bariéry podnikania v elektronickom obchode (čast' 1). Pošta, telekomunikácie a elektronický obchod, Žilina: Žilinská univerzita, 2016, s. 21-26. ISSN 1336-8281

[4] KIM, S.I., KIM, S.H.: E.commerce payment model using blockchain. Journal of Ambient Intelligence and Humanized Computing, 2020. DOI: 10.1007/s12652-020-02519-5

[5] Elektronický platobný systém. Spôsob platby. Čo je to elektronická platba? 2019. [online]. Dostupné na: https://beasthackerz.ru/sk/vkontakte/elektronnaya-platezhnayasistema-sposoby-oplaty-chto-takoe-elektronnyi.html

[6] Čo sú elektronické platobné systémy. Elektronické platby a elektronické platobné systémy. [online]. Dostupné na: https://totrdlo.ru/sk/chto-takoe-sistemy-elektronnyhplatezhei-elektronnye-platezhi-i.html

[7] KHAN, B.U. A KOL.: A Compendious Study of Online Payment Systems: Past Developments, Present Impact, and Future Consideration. International Journal of Advanced Computer Science and Applications, 2017, s. 256-271

[8] DOMINIC, L.: How to Define E-Payments. [online]. Dostupné na: https://securionpay.com/blog/how-to-define-e-payments/

[9] BORTŇÁKOVÁ, L'.: E-platby: najrýchlejší spôsob úhrady na internete. 2019. [online]. Dostupné na: https://www.investujeme.sk/clanky/e-platby-najrychlejsi-sposob-uhradyna-internete/

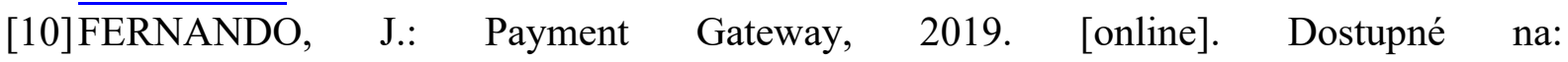
https://www.investopedia.com/terms/p/payment-gateway.asp 
[11]Čo je to platobná brána a ako vybrat' tú správnu? 2020. [online]. Dostupné na: https://podnikam.sk/co-je-to-platobna-brana-a-ako-vybrat-tu-spravnu/

[12] MARKOVÁ, J.: Vyberáme platobnú bránu pre slovenský alebo český eshop, 2020. [online]. Dostupné na: https://www.webhostingcentrum.sk/platobne-brany-pre-eshopy/

[13] SUDHIR, N.: Everything You Need To Know About A Payment Gateway Process Cycle, 2016. Dostupné na: https://www.pixelmattic.com/blog/payment-gateway-process-cycle/

[14]BRESLAW, D.: Best International Payment Platforms for eCommerce in 2020, 2020. Dostupné na: https://blog.payoneer.com/e-sellers/payments/best-internationalecommerce-payment-platforms/

[15] FEARN, N., DEMURO, J.P., TURNER, B.: Best payment gateways of 2020: for payment processing online, 2020. Dostupné na: https:/www.techradar.com/best/bestpayment-gateways

[16]LOFGREN, L.: 11 Best Payment Methods For Your Ecommerce Site, 2020. Dostupné na: $\quad$ https://www.quicksprout.com/best-payment-methods-for-your-ecommercesite/\#Paypal

[17] MCCOY, J.: Top 10 Most Popular Online Payment Solutions, 2020. Dostupné na: https://www.searchenginejournal.com/most-popular-online-paymentsolutions/355014/\#close

[18]Adyen Reviews. Dostupné https://www.trustradius.com/products/adyen/reviews?qs=pros-and-cons

[19] SOFFAR, H.: What are the advantages and disadvantages of using PayPal?, 2020. Dostupné na: https://www.online-sciences.com/technology/what-are-the-advantages-anddisadvantages-of-using-paypal/

\section{Grantová podpora}

Príspevok bol spracovaný v rámci riešenia projektu 1/0152/18 VEGA Obchodné modely a platformy $\mathrm{v}$ digitálnom prostredí. 